\title{
Application of Bokashi Botom Ash for Increasing Upland Rice Yield and Decreasing Grain Pb Content in Vitric Hapludans
}

\author{
Nunung Sondari and Ervina Siti Nurkhalidah \\ Faculty of Agriculture, Winaya Mukti University, Jl. Raya Bandung - Sumedang km 29 Tanjungsari 45462, \\ West Java, Indonesia, e-mail: nunung_1962@yahoo.com, telp: +62-22-7912585.
}

Received 22 December 2010 / accepted 28 April 2012

\begin{abstract}
Greenhouse experiment was conducted at Agricultural Faculty of Winaya Mukti University Tanjungsari Sumedang Regency, from May to October 2009. The objective of this experiment was to study the effect of bokashi bottom ash on the growth, yield, and $\mathrm{Pb}$ content of upland rice. The experiment used a Randomized completely Block Design (RBD) which consisted of five treatments and five replications. The treatments were level of bokashi bottom ash i.e. $0,5,10,15$, and $20 \mathrm{Mg} \mathrm{ha}^{-1}$. The results showed that the application of bokashi bottom ash increased the growth and yield of upland rice of Situbagendit variety except plant height at age of 21 days after seedling (DAS). Application $15 \mathrm{Mg} \mathrm{ha}^{-1}$ of bokashi bottom ash gave the best effect to the plant height, number of leaves, number of tillers and shoot/root ratio, while applications of 10,15 and $20 \mathrm{Mg} \mathrm{ha}^{-1}$ increased number of productive tillers, amount of filled grains, and weight of grains. Bokashi bottom ash did not affect the heavy metal content of upland rice grain of Situbagendit variety.
\end{abstract}

Keywords: Bokashi bottom ash, $\mathrm{Pb}$ heavy metal, upland rice

\section{INTRODUCTION}

The utilization of coal combustion waste is beneficial to increase the agricultural productivity. Bottom ash is one of the coal combustion waste. In America and India, bottom ash has been utilized as an ameliorant (a substance to make the marginal soils better) (Kishor et al. 2010; Sondari 2005; Stevens and Dunn 2004). Kumar et al. (2000) reported that the ash from the residual burnt coal can be utilized as a soil ameliorant for subtropical plants such as oats, wheat, and barley. Bokashi bottom ash as a solid organic fertilizer is made from mixed raw materials fermentation which are 50\% bottom ash, $20 \%$ rice straw, $20 \%$ chicken manure, $10 \%$ bran, Effective Microorganism $\left(\mathrm{EM}_{4}\right)$, molasses, and water. Bokashi bottom ash can be used as a solid organic fertilizer after 14 days of fermentation.

One of the efforts in utilizing bottom ash is by using it as the main substance in bokashi production. According to ACAA (1997), the chemical substance in bottom ash is highly depended on the coal source. Chemically, bottom ash contains some nutrients, especially the micro elements. The nutrients are

J Trop Soils, Vol. 17, No. 2, 2012: 157-163

ISSN 0852-257X highly potential and necessary for better plant growth where the fertile soils have fell on the degradations (Sondari 2005). Bokashi bottom ash is expected to increase the plant productivity. However, the use of bottom ash is feared to be the contributor of heavy metal in the soils which is absorbed by the plant.

The application of bottom ash which is mixed with the green manure can improve the soil physical and chemical properties and also increases the result of sorghum in the typic kanhaplidults (Sondari 2006). Sondari (2009) further suggested that the result of the bokashi bottom ash application compared to the bottom ash that was created to be manure (bokashi bottom ash), showed that bokashi bottom ash was better in increasing the upland rice production than the one with bottom ash only.

Bottom ash as one of coal combustion waste is a solid waste which is produced by the coal combustion. The coal combustion waste can be classified into a Dangerous and Poisonous Substance, based on PP No. 18/1999, and PP No.85/ 1999 about The Management of Waste as Dangerous and Poisonous Substance (KLH RI 2010). Bottom ash contains oxides heavy metal which will leach naturally and pollute the environment (Chen et al. 2008; Veli et al. 2008).

Increasing of metal concentration in agricultural lands, especially heavy metal, produces serious effect to the whole form of life. The use of bottom 
ash combining with chicken manure, EM, bran, hay and chaff as the main substance of bokashi can decrease the content of heavy metal because of the chelate process. According to Cooper et al. (1999) chelate is the reaction between heavy metal and organic compounds which are produced in the decomposition of organic matter. After becoming bokashi, the bottom ash will give more positive contributions to the soils and the plants.

Every plant has different sensitivity to heavy metal and also shows different ability in accumulating the heavy metal. Upland rice which is one of food crops is classified in gramineae family, which is highly potential to be planted in dry lands. The average results of upland rice in Indonesia are still relatively low, less than $2 \mathrm{Mg} \mathrm{ha}^{-1}$, and it is for behind compared to the potential of its production (CRD 2008).

Low productivity of upland rice in Indonesia due to it is planted in dry lands. Planting rice in dry lands has some constrains which are caused by the land limitation. Dry lands in Indonesia mostly include Red Acid Soils in which easily eroded, less nutrients, high level of acidity, and also content of organic matter easily decrease if the soil is used.

The objective of this research was to study the effect of bokashi bottom ash on upland rice (Oryza sativa. $\mathrm{L}$ ) growth, yield, and $\mathrm{Pb}$ content grain in Vitric Hapludants.

\section{MATERIALS AND METHODS}

\section{Study Site and Materials}

Soil was taken from Tanjungsari, West Java with some properties which were soil $\mathrm{pH} 5.27$, organic - $\mathrm{C}(4.05 \%)$, total- $\mathrm{N} 0.22 \%$ (medium), $\mathrm{K}_{2} \mathrm{O}$ $18.43 \mathrm{mg} 100 \mathrm{~g}^{-1}$ (low), available P $4.51 \mathrm{mg} \mathrm{kg}^{-1}$ (very low); exchangable $\mathrm{Na}\left(0,007 \mathrm{cmol} \mathrm{kg}^{-1}\right.$, very low); $\mathrm{Ca}$ (5.9 $\mathrm{cmol} \mathrm{kg}^{-1}$, medium); $\mathrm{Mg}(0.91 \mathrm{cmol}$ $\mathrm{kg}^{-1}$, low $)$; $\mathrm{K}\left(0.26 \mathrm{cmol} \mathrm{kg-1}^{-1}\right.$, low $)$. Soil is classified as Vitric hapludant. Upland rice seed was certified Situbagendit variety and bottom ash bokashi of coal combustion waste was taken from a textile factory in West Java. Others materials were chicken manure, rice husks, straw, bran, Effective Microorganism (EM 4), sugar water, Furadan $3 \mathrm{G}$, urea $(45 \% \mathrm{~N})$, SP-36 $\left(36 \% \mathrm{P}_{2} \mathrm{O}_{5}\right)$ and $\mathrm{KCl}\left(58 \% \mathrm{~K}_{2} \mathrm{O}\right)$.

The properties of Bokashi bottom ash were water content $(12.19 \%)$, acidity $(\mathrm{pH}) 8.7$ (base), organic-C (7.08\%); macro element: total-N (0.61 $\%), \mathrm{C} / \mathrm{N}$ ratio (12), $\mathrm{P}_{2} \mathrm{O}_{5}(0.53 \%) ; \mathrm{K}_{2} \mathrm{O}(0.57 \%)$; $\mathrm{CaO}(5.376 \%)$; total-Mg (1.53\%) and $\mathrm{S}(0.17 \%)$; micro element: total-Fe $(1.71 \%)$; total $-\mathrm{Cu}$
$(0.0014 \%)$; total-Zn $(0.006 \%)$ and total-B $(0.027 \%)$ and $\mathrm{Pb}$ heavy metal $\left(5.9 \mathrm{mg} \mathrm{kg}^{-1}\right)$.

\section{Experimental Set Up}

The experiment used a Randomized completely Block Design (RBD), consisted of 5 treatments and 5 replications. The treatment was the application rate of bokashi bottom ash, i.e. 0, 5, 10,15 , and $20 \mathrm{Mg} \mathrm{ha}^{-1}$.

Soils $(10 \mathrm{~kg})$ were filled into polybag (without hole). Fertilizers were applied together with the application of bokashi bottom ash in each polybag in accordance with each treatment a two weeks before planting. Fertilizers and bokashi bottom ash were mixed thoroughly the soil, then they were incubated for two weeks. Fertilizers used were urea $(45 \% \mathrm{~N}), \mathrm{SP}-36\left(36 \% \mathrm{P}_{2} \mathrm{O}_{5}\right)$, and $\mathrm{KCl}\left(58 \% \mathrm{~K}_{2} \mathrm{O}\right)$ with the dosage of $150 \mathrm{~kg} \mathrm{ha}^{-1}, 135 \mathrm{~kg} \mathrm{ha}^{-1}$, and 135 $\mathrm{kg} \mathrm{ha}^{-1}$, respectively. Then, the upland rice seed was planted two seed per polybag. The plants were maintained everyday for water, pest and plant disenses.

\section{Data Observation and Analysis}

The observations were done at harvest time when the age of upland rice was 126 days. Data of plant height, number of leaves per hill, number of tillers per hill, shoot root ratio, number of productive tillers per hill, amount of filled grains per hill, weight of grains and content of $\mathrm{Pb}$ in rice grain were collected. Determination of heavy metals in rice grains was done through dry ashing method with $\mathrm{MgNO}_{3}$ reagents in ethanol. Data were analyzed by respons curve and regression analysis.

\section{RESULTS AND DISCUSSION}

\section{Plant Growth Component}

The application of bokashi bottom ash for upland paddy rice reached optimum plant height was at the rate of $15 \mathrm{Mg} \mathrm{ha}^{-1}$. The more dosage applied yielded stable plant height for all day after seedling (DAS) as shown in Figure 1. The number of leaves per hill and tiller per hill also reached maximum number with the rate of bokashi bottom ash $15 \mathrm{Mg}$ ha $^{-1}$ at 6 DAS (Figure 2 and Figure 3), and the higher rate of bokashi showed the decreasing number of leaves.

\section{Shoot /Root Ratio}

The application of bokashi bottom ash for upland paddy rice reached optimum shoot/root ratio at the dosage of $15 \mathrm{Mg} \mathrm{ha}^{-1}$. More higher dosage 


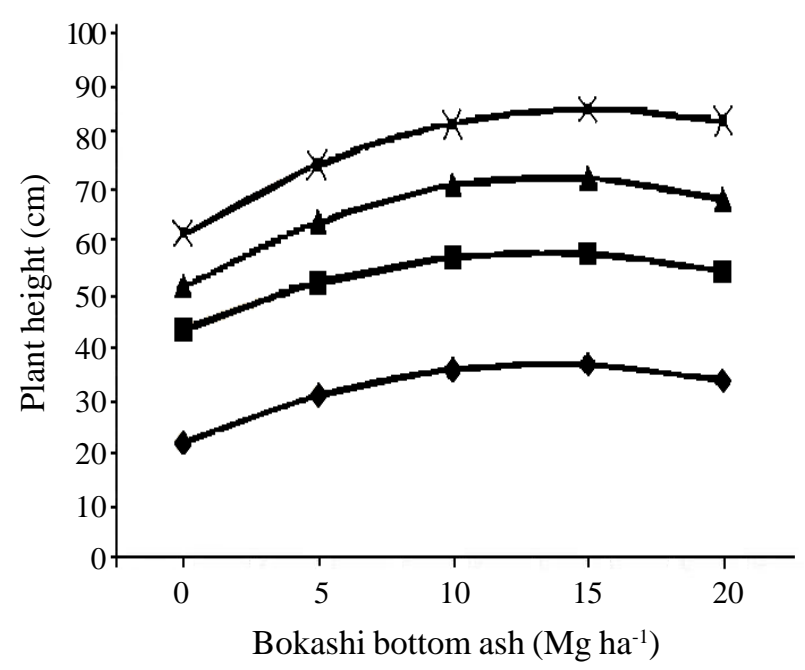

Figure 1. Effect of bokashi bottom ash rates on plant height of upland rice. $-(21$ DAS $), y=$ $22.11+2.20 \mathrm{x}-0.08 \mathrm{x}^{2}, \mathrm{R}^{2}=0.81,-\mathbf{-}(35$ DAS), $\mathrm{y}=43.63+2.21 \mathrm{x}-0.08 \mathrm{x}^{2}, \mathrm{R}^{2}=$ $0.85, \underset{\mathbf{L}}{\mathbf{L}}(49 \mathrm{DAS}), \mathrm{y}=51.86+3.01 \mathrm{x}-$ $0.11 \mathrm{x}^{2}, \mathrm{R}^{2}=0.90$, and $\nVdash(63 \mathrm{DAS}), \mathrm{y}=$ $62.22+3.08 \mathrm{x}-0.10 \mathrm{x}^{2}, \mathrm{R}^{2}=0.94$.

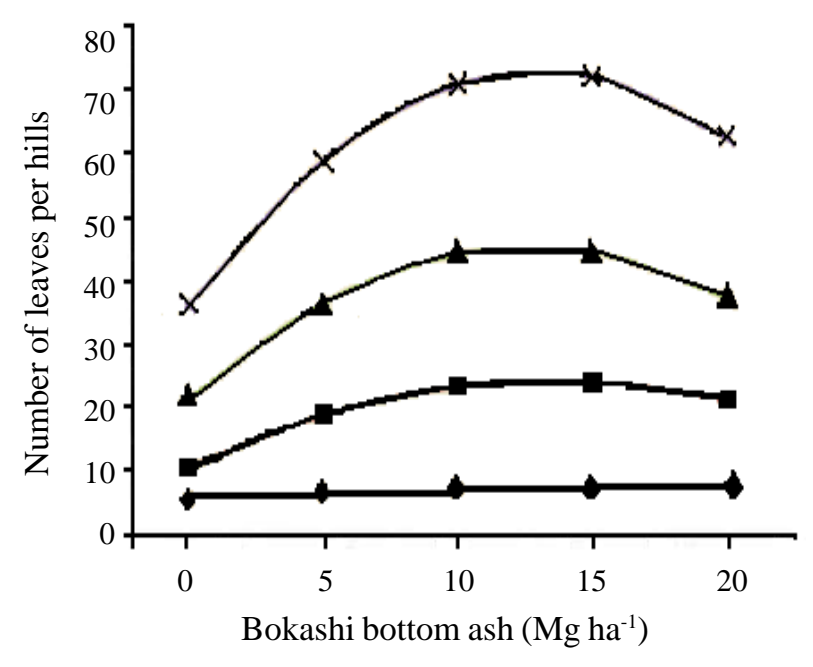

Figure 2. Effect of bokashi bottom ash rates on number of leaves per hills. $\longrightarrow$ (21 DAS), $\mathrm{y}=$ $5.50+0.18 \mathrm{x}, \mathrm{R}^{2}=0.77, \boldsymbol{-}(35 \mathrm{DAS}), \mathrm{y}$ $=10.65+2.01 \mathrm{x}-0.07 \mathrm{x}^{2}, \mathrm{R}^{2}=0.82, \mathbf{A}$ (49 DAS), $y=21.41+3.74 \mathrm{x}-0.15 \mathrm{x}^{2}, \mathrm{R}^{2}$ $=0.82$, and $\asymp(63$ DAS $), y=36.09+$ $5.62 \mathrm{x}-0.22 \mathrm{x}^{2}, \mathrm{R}^{2}=0.83$.

decreased shoot/root ratio as shown in Figure 4. It is shown that without application of bokashi caused the low rate of shoot/ root ratio. The highest rate of bokashi application $20 \mathrm{Mg} \mathrm{ha}^{-1}$ reduced shoot root ratio, the optimum rate of bokashi $15.31 \mathrm{Mg} \mathrm{ha}^{-1}$ gave the highest rate of 2.3 shoot /root ratio.

\section{Yield Component}

The number of productive tiller per hill reached maximum with the dosage of $20 \mathrm{Mg} \mathrm{ha}^{-1}$, however, without the application of bokashi the filled grain per hill number and the number of productive tiller decreased. It also happened when it was applied with the higher rate of bokashi. The maximum number of productive tillers which was 16.82 pieces, was reached from the optimum application of bokashi 19.15 $\mathrm{Mg} \mathrm{ha}^{-1}$ (Figure 5) and the weight of grain per hill reached maximum with the rate of bokashi bottom ash $14.30 \mathrm{Mg} \mathrm{ha}^{-1}$ (Figure 6). It showed that

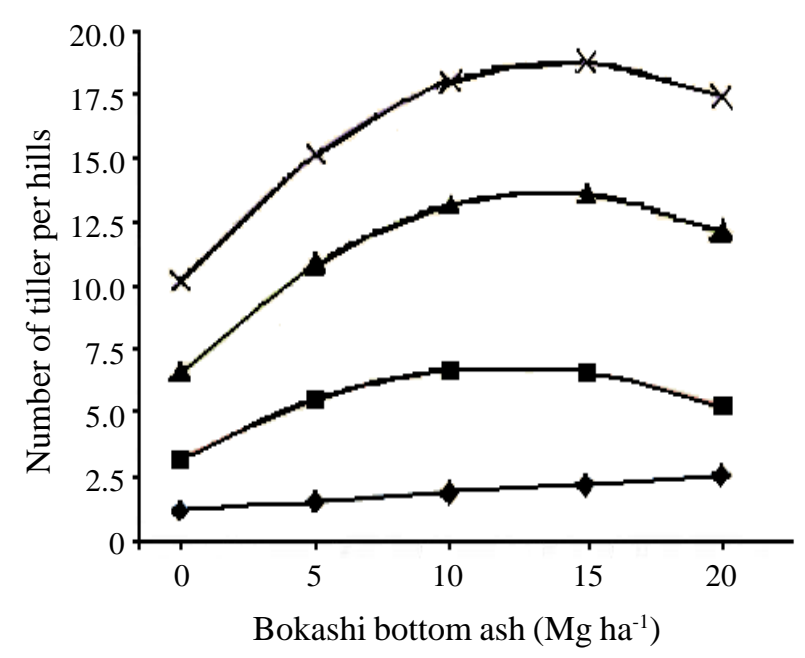

Figure 3. Effect of bokashi bottom ash rates on the number of tiller per hills. $\leadsto$ (21 DAS), y $=1.22+0.07 \mathrm{x}, \mathrm{R}^{2}=0.73,-\mathbf{-}(35 \mathrm{DAS}), \mathrm{y}$ $=3.20+0.60 \mathrm{x}-0.24 \mathrm{x}^{2}, \mathrm{R}^{2}=0.78, \mathbf{-}-$ (49 DAS), $\mathrm{y}=6.57+1.04 \mathrm{x}-0.04 \mathrm{x}^{2}, \mathrm{R}^{2}=$ 0.81 , and $\longleftarrow$ (63 DAS), $\mathrm{y}=10.20+1.20 \mathrm{x}$ $-0.04 x^{2}, R^{2}=0.82$.

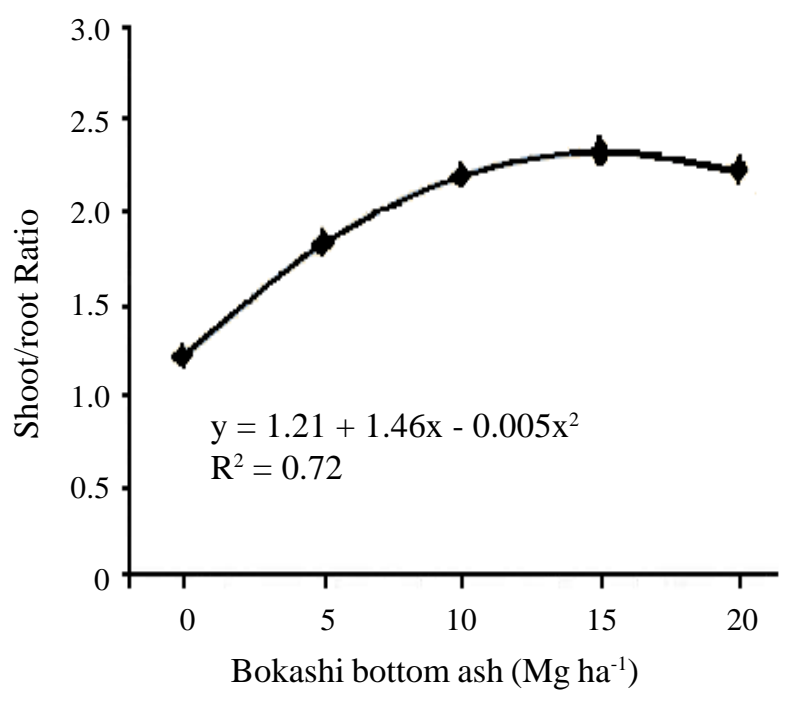

Figure 4. Effect of bokashi bottom ash rates on the shoot/root ratios. 


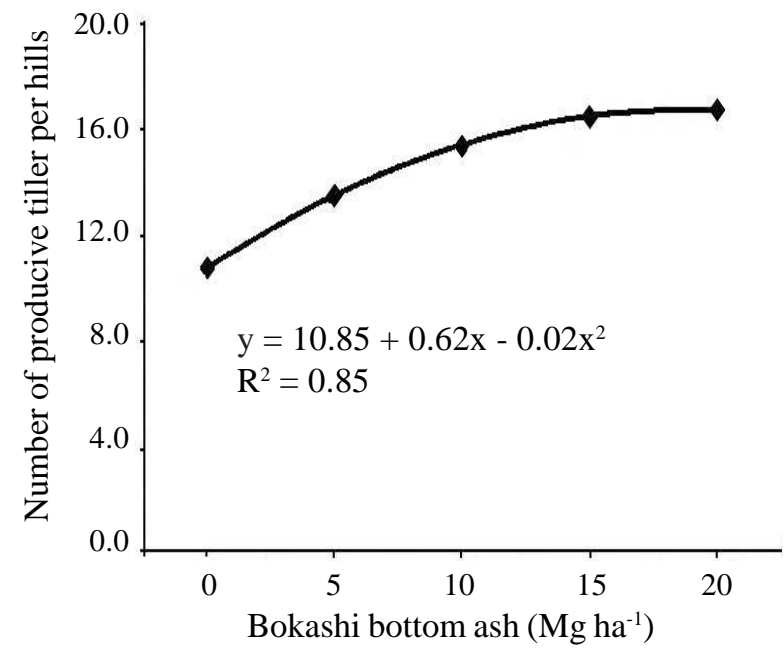

Figure 5. Effect of bokashi bottom ash rates to number of productive tiller per hill.

without the application of bokashi, amount of filled grains were low, and also the higher rate of bokashi application also reduced amount of filled grains. The optimum rate of bokashi showed the highest amount of filled grains which were 13,553.58 pieces. Figure 7 showed that the optimum rate of bokashi 14.28 $\mathrm{Mg} \mathrm{ha}^{-1}$ gave the best effect to the highest weight of grains which was $28.6 \mathrm{~g}$ per hill.

\section{Pb Uptake by Grain}

The application of bokashi bottom ash decreased slightly grain $\mathrm{Pb}$ uptake by the grain of upland rice as shown in Figure 8. There was a tendency that the highest rate of bokashi application caused the low $\mathrm{Pb}$ content.

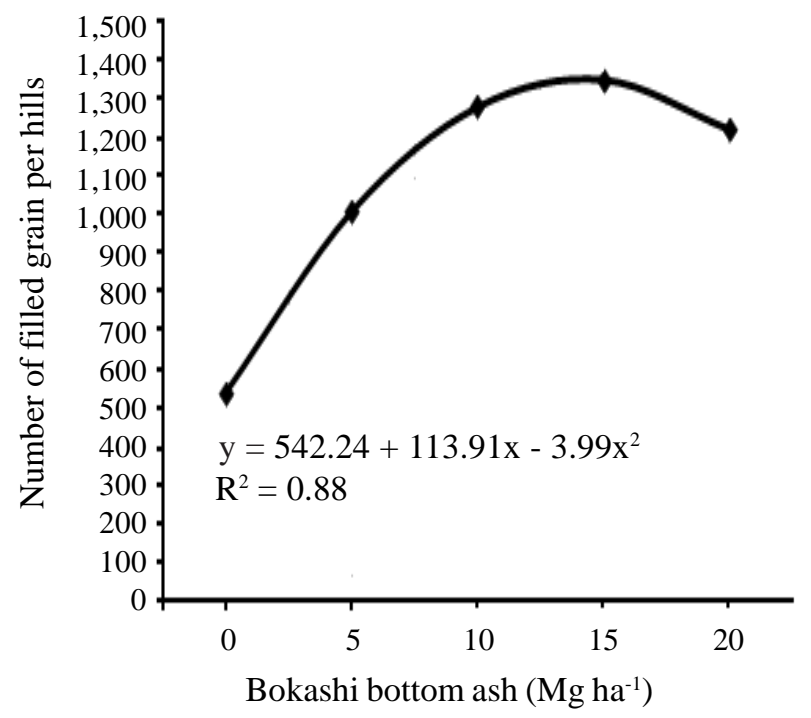

Figure 6. Effect of bokashi bottom ash rates on number of filled grain per hill.

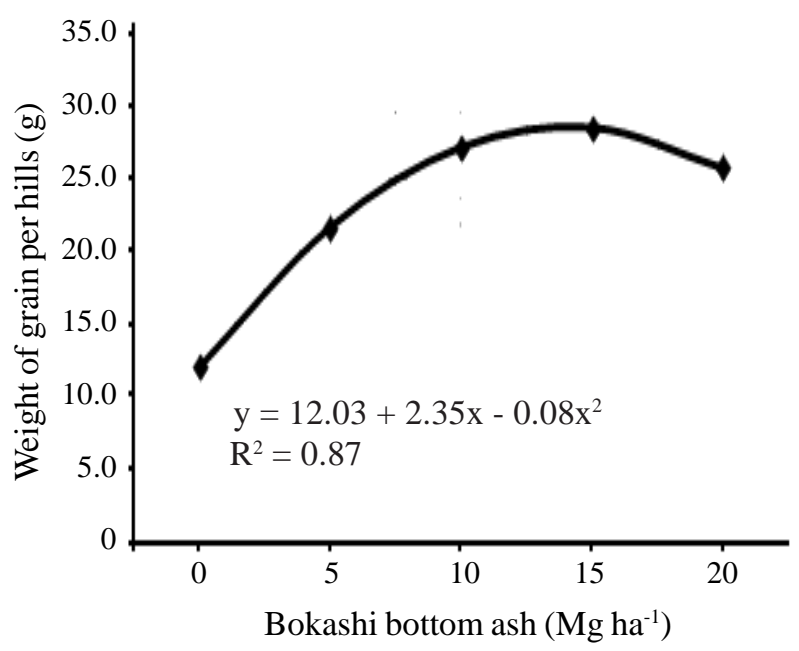

Figure 7. Effect of bokashi bottom ash rates to weight of grains per hill.

\section{Discussion}

Application of the bokashi bottom ash could affect the growth components and yield. The effect of bokashi bottom ash to the plant growth was seen at 35, 49 and 63 DAS age. At 21 DAS age, however, bokashi bottom ash did not show a significant effect to the plant growth. Number of leaves per hill and number of tiller per hill at 21, 35, 49 and 63 DAS age increased significantly with application of bokashi bottom ash. It way likely that the plants still had enough food supplies, from rice seed attached to the root-shoots so that the addition of nutrients from the soil was still in a small quantity and only increased number of leaves and tillers.

The application of bottom ash bokashi increased shoot-root ratio where the better results of shootroot ratio were at the dosage of $15 \mathrm{Mg} \mathrm{ha}^{-1}$ and 20

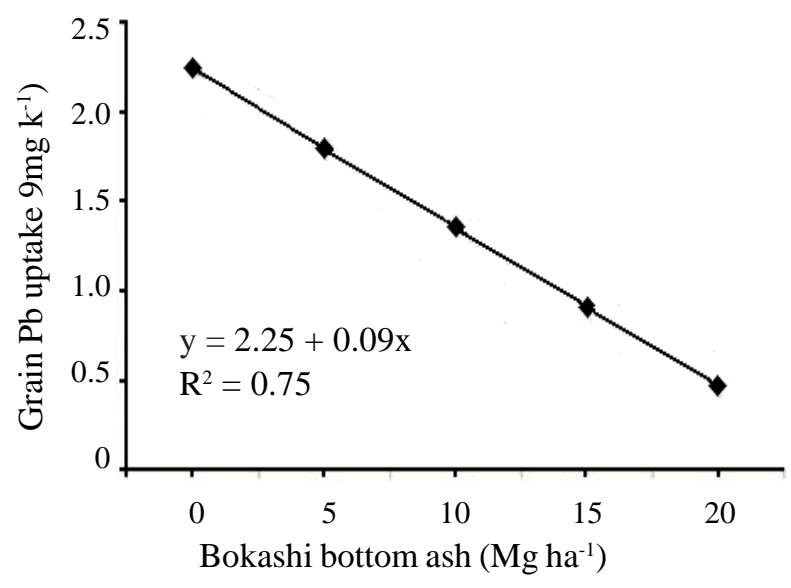

Figure 8. Effect of bokashi bottom ash rates on the $\mathrm{Pb}$ grain uptake by upland rice. 
$\mathrm{Mg} \mathrm{ha}^{-1}$, and quantitatively decreased when the rates was more than $20 \mathrm{Mg} \mathrm{ha}^{-1}$. At $15 \mathrm{Mg} \mathrm{ha}^{-1}$ level the plant could absorb the nutrients from the soils well, so that the addition of bokashi did not have any effect to the plant.

Bokashi bottom ash is an organic material, however it can supply nutrients for the plant growth. Bottom ash is solid waste from coal combustion and contains important nutrients, namely sodium, magnesium, and potassium. Moreover, it can improve the $\mathrm{pH}$ of acid soils so that $\mathrm{Al}$ activity decreases.

The effect of bokashi bottom ash to the plant growth showed that the lowest rate of plant growth was when it was not applied with bokashi. However, the higher rate of bokashi application showed the decreasing of plant growth.

In accordance to Figure 2 showed that number of leaves which were applied with the higher rate of bokashi showed the decreasing number of leaves. This was because of micro nutrient content in bokashi such as Fe (1.71\%), Zn (0.006\%), and B $(0.03 \%)$ which were absorbed exceeding the needs of the plant .

Decreasing growth when bokashi bottom ash was added to $20 \mathrm{Mg} \mathrm{ha}^{-1}$ happened because of the excess nutrients, such as Fe (1.708\%) and $\mathrm{Zn}$ $(0.006 \%)$ which were absorbed exceeding the needs of the plant because sufficient limit of Fe for rice 20 - $250 \mathrm{ppm}$ and Zn 20 - 70 ppm (Mengel and Kirkby 1987; Jones et al. 1991), in accordance with the growth curve which consists of three parts. In the first part, the growing rate increased together with the increasing of nutrient supply (deficient), on the second part the growing rate reached maximum and was not affected by the nutrient supply (sufficient) and on the third part, the growing rate decreased with the increasing of the nutrient supply (toxic) (Marschner 1986).

Bokashi bottom ash gave the significant effect to the number of productive tillers, amount of filled grains and grain weight. Meanwhile, to the weight of 100 grains, bokashi bottom ash did not give a significant effect. This was because of the genetic traits of the upland rice of Situbagendit variety itself.

Bokashi bottom ash increased the component of the upland rice production and the better results were in the dosages of bokashi at $10 \mathrm{Mg} \mathrm{ha}^{-1}$, $15 \mathrm{Mg} \mathrm{ha}^{-1}$ and $20 \mathrm{Mg} \mathrm{ha}^{-1}$, however quantitatively there is a regression when the dosage was $20 \mathrm{Mg}$ $\mathrm{ha}^{-1}$. The increase of the variable was caused by bokashi bottom ash which was able to create a favorable environment so that the soil provided nutrients for plants. Plants require macro and micro nutrients which are important for their growth, such as nitrogen, phosphorus, potassium, calcium, magnesium, zinc, iron, boron, sulfur, and copper, so that it will increase the harvest. Application of bokashi bottom ash produced the availability of the macro and micro nutrients which were important for plant growth. According to Harjadi (1991), the carbohydrates from the photosynthesis process is stored mostly in food reserves such as leaf, stem, and root as starch or amilum. This caused the weight of grains in bokashi bottom ash treatment increased.

The decrease of the grain yield at application of $20 \mathrm{Mg} \mathrm{ha}^{-1}$ bokashi bottom ash was due to the plant has received the optimal nutrients at $15 \mathrm{Mg}$ $\mathrm{ha}^{-1}$ bokashi level so that when the level is increased then it would not give any effect. When the supply of growing factors such as sunlight, $\mathrm{CO}_{2}$, water and nutrients are increasing, the growing rate and the plant production will increase too although with the decreased increasing or called Law of Diminishing Yield Increment (Willcox 1954).

The use of bokashi bottom ash affected plant growth and yield, in the other hand, the use of bokashi bottom ash did not directly affect the content of heavy metal lead $(\mathrm{Pb})$ in the grains.

The lead is mostly accumulated by the plant organs, such as leaf, stem, root and the root tubers. The transfer of $\mathrm{Pb}$ from the soil to the plant depends on soil and CEC. High concentration of $\mathrm{Pb}$ (100 $1,000 \mathrm{mg} \mathrm{kg}^{-1}$ ) will cause the toxic effect to the photosynthesis and growing process. Lead only affects the plants if its concentration is high (Sharma and Dubey 2005). The plant absorbs the $\mathrm{Pb}$ metal at low of fertile soil condition, content of the organic matter, and also CEC. In this condition, the heavy metal $\mathrm{Pb}$ will detach from the soil bond, transform into ion which moves freely in the soil solution. If the other metal cannot obstruct its existence, the root plant will absorb the $\mathrm{Pb}$.

According to the statistical analysis, application of bokashi bottom ash did not give any significant affect to the $\mathrm{Pb}$ content in the rice grains. The biggest $\mathrm{Pb}$ content in the rice grains was at central treatment, where the $\mathrm{Pb}$ content in the soil contributed the $\mathrm{Pb}$ content in the rice grains. Based on the soil analysis before experiment, $\mathrm{Pb}$ content in the soil was high which was about $30 \mathrm{mg} \mathrm{kg}^{-1}$. The smallest $\mathrm{Pb}$ content in the plant $\left(1.034 \mathrm{mg} \mathrm{kg}^{-}\right.$ $\left.{ }^{1}\right)$ was at bokashi rates of $20 \mathrm{Mg} \mathrm{ha}^{-1}$. This was because it contained highest organic matter than other treatments. Organic matter was able to bind heavy metal $\mathrm{Pb}$ through chelasilisation so that the heavy metal $\mathrm{Pb}$ in the rice grains was low. Nurjaya et al. (2006) mentioned that the mechanism of $\mathrm{Pb}$ 
adsorption by organic matter treatment through the negative charged carboxyl group that bind the $\mathrm{Pb}$ to form chelate so that plant did not absorb it.

Soil acidity is one of the factors that affect the labile fraction of heavy metals in the soil. The labile fraction of heavy metals decreases as the soil acidity increases and this decreasing is caused by the increasing of soil's adsorption potency as a result of the dehydrogenises of various functional groups in the soil that is stimulated by the increasing of the ion $\mathrm{OH}$ - activity. The addition of organic matters can increase rate of adsorption of heavy metals (Sauve et al. 1998; Park et al. 2011).

To obtain a safe grain or rice, it is required a planting media and production input which are not polluted. According to Kasno et al. (2000), paddy rice from polluted land contained cadmium $>0.12$ $\mathrm{mg} \mathrm{kg}^{-1}$ and lead $>0.5 \mathrm{mg} \mathrm{kg}^{-1}$. Bokashi bottom ash dosage decreased heavy metal $\mathrm{Pb}$ content in rice grains, although it was still above the permitted threshold which was above $1 \mathrm{mg} \mathrm{kg}^{-1}$.

\section{CONCLUSIONS}

The application of the bokashi bottom ash increased the growth and yield of upland rice of Situbagendit variety, except for plant height at age of $21 \mathrm{DAS}$. Bokashi bottom ash at $15 \mathrm{Mg} \mathrm{ha}^{-1}$ level gave the best effect to the plant height, number of leaves, number of tillers, and shoot root ratio, while at 10,15 and $20 \mathrm{Mg} \mathrm{ha}^{-1}$ level increased number of productive tillers, amount of filled grains, and weight of grains. Bokashi bottom ash did not affect the heavy metal content in the upland rice grain of Situbagendit variety. This research is preliminary, it is necessary to do further research on the same soil and on different place (field) with a rate of $10 \mathrm{Mg} \mathrm{ha}^{-1}$ to $20 \mathrm{Mg} \mathrm{ha}^{-1}$ so that the information about bokashi bottom ash dosage can be known completely. Besides that, it is necessary to study the effects of the application of bokashi bottom ash.

\section{REFERENCES}

ACAA [American Coal Ash Assosiation]. 1997. Coal Combustion Pruduct-Production and Use. Alexandria, Virginia. Available online at http:// www.tfhrc.gov/hnr/recycle/waste. Accessed on 29 February 2004.

Chen CK, C Lin, LC Wang, YC Lin and GPC Chien. 2008. Size distribution of metals in bottom ash of municipal solid waste incinerators. J Environ Eng Manage 18 (2): $105-115$
Cooper EM, JT Sims, SD Cunningham, JW Huang and WR Berti. 1999. Chelate-assisted phytoextraction of lead from contaminated soils. J Environ Qual 28: 1709-1719.

CRD [Center of Research and Development]. 2008. Opportunity to gain sustainable rice production.National Department of Agriculture. Bogor.

Harjadi SS. 1991. Pengantar Agronomi. Gramedia. Jakarta (in Indonesian).

Harjowieno S. 1995. Ilmu Tanah. Akademika Pressindo, Jakarta (in Indonesian).

Jones B, W Benyamin and AM Harry. 1991. Plant analisis Hand Book. A practice sampling, preparation, analisys and interpretation guide. Micro Macro Publishing, Inc. Georgia.

Kasno A, S Adiningsih, Y Sulaeman and Subowo. 2000. Status pencemaran lead dan cadmium pada padi sawah intensifikasi jalur Pantura Jawa Barat. J I Tanah Lingk 3 (2): 25-32 (in Indonesian).

Kishor P, AK Ghosh and D Kumar. 2010. Use of flyash in agriculture: A way to improve soil fertility and its productivity. Asian J Agric Res 4 (1): 1-14.

KLH RI [Kementrian Lingkungan Hidup Republik Indonesia]. 2010. Himpunan Peraturan Perundang-undangan di Bidang Perlindungan dan Pengelolaan Lingkungan Hidup (Jilid 1). PP No.18 Tahun 1999 tentang Pengelolaan Limbah Bahan Berbahaya dan Beracun dan PP No. 85 Tahun 1999 tentang Perubahan Atas Peraturan Pemerintah No. 18 Tahun 1999 tentang Pengelolaan Limbah Bahan Berbahaya dan Beracun. Jakarta (in Indonesian).

Kumar V, G Goswami and KA Zacharia. 2000. Flyash in Agriculture. A Prespective News and Views. TIFAC. http://www.tifac.org.in/news. Accessed on 5 August 2003.

Marschner H. 1986. Mineral Nutrition of Higher Plants. Academic Press. Harcott Jovanovich Publisher. Tokyo.

Mengel K. and EA Kirkby. 1987. Principles of Plant Nutrition. $4^{\text {th }} e d$. Completely revised. International Potash Institute, Switzerland.

Nurjaya A, Emona, Zihan. and MS Saeni. 2006. Pengaruh amelioran terhadap kadar $\mathrm{Pb}$ tanah, serapannya serta hasil tanaman bawang merah pada Inceptisol. J I Pert Indon 8: 110-119.

Park BJ, J Lee and WI Kim. 2011. Influence of soil characteristics and arsenic, cadmium, and lead contamination on their accumulation levels in rice and human health risk through intake of rice grown nearby abandoned mines. J Korean Soc Appl Biol Chem 54 (4): 575-582.

Sauve S, M McBride and W Hendershot. 1998. Soil solution specification of lead (II): Effect of organic matter and pH. Soil Sci Soc Am J 62 (3): 618-621.

Schlossberg MJ, CP Vanags and WP Miller. 2003. Bermudagrass sod growth and metal uptake in coal combustion by-product-amended media. J Environ Qual 33: 740-748. 
Sharma P and RS Dubey. 2005. Lead toxicity in plants. Braz J Plant Physiol 17 (1): 35-52.

Sondari N. 2006. N-total dan P-tersedia Tanah serta Hasil Hermada / Sorghum Akibat Pemberian Bottom Ash dan Pupuk Hijau pada Typic Kanhapludults. J Wacana Pert V: 45-50.

Sondari N. 2005. Beberapa Sifat Fisika dan Kimia Tanah, Konsentrasi Hara, serta Hasil Hermada (Sorghum bicolor L. Moench) akibat Pemberian Abu Sisa Bakaran Batubara (ASBB) dan Pupuk Hijau pada Typic Kanhapludults. [Dissertation] Program Pasca Sarjana Universitas Padjadjaran Bandung (in Indonesian).
Sondari, N. 2009. Pertumbuhan kadar logam berat pb dan hasil padi gogo (Oryza sativa L.) akibat pemberian kombinasi limbah batubara bottom ash dan bokashi bottom ash. J I Tanah Lingk 9 (2): 88-94.

Stevens G and D Dunn. 2004. Fly ash as a liming material for cotton. J Environ Qual 33: 343-348.

Veli S, L Kirli, B Alyuz and E Durmusoglu. 2008. Characterizaion of bottom ash, fly ash, and filter cake produced from hazardous waste incineration. Polish J Environ Stud 17 (1): 139-145.

Willcox OW. 1954. Quantitative agrobiology: III. The Mitscherlich equation and its constants. Agron $J$ 46: 323-326. 